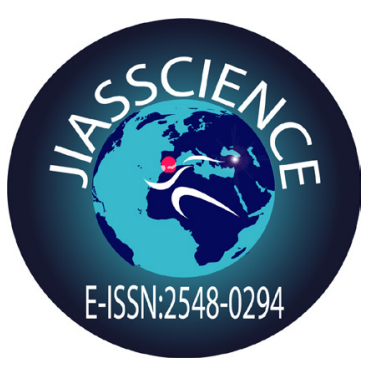

The Journal of International Anatolia Sport Science

Vol. 3, No. 3, December, 2018

\title{
THE EFFECTS OF AEROBIC AND ANAEROBIC TRAINING ON AEROBIC AND ANAEROBIC CAPACITY
}

\author{
Hasan Sözen ${ }^{1}$, Can Akyıldız \\ ${ }^{1}$ University of Ordu, Department of Physical Education and Sport, Altınordu, Ordu, Turkey
}

\begin{abstract}
Aerobic capacity is the capacity of large skeletal muscle groups to adapt to work by using energy obtained as a result of aerobic metabolism. VO2max is a good indicator of aerobic capacity and is considered to be an indicator of the physiological integration of pulmonary, cardiovascular and neuromuscular functions. Anaerobic capacity is the ability of the muscles to adapt to workouts in the form of very short duration, maximal and supramaximal physical activities. The aim of this study is to investigate the effects of aerobic and anaerobic training methods on aerobic and anaerobic capacity. 8 female (age; $18.12 \pm 0.35$ years, weight 46.6 $\pm 7.39 \mathrm{~kg}$; height $162.7 \pm 6.75 \mathrm{~cm}$; BMI; $17.72 \pm 2.60$ $\mathrm{kg} / \mathrm{m} 2$, PBF; $16.01 \pm 6.15 \%$ ) and 8 male (age; 18.50 \pm 1.19 years, weight $61.18 \pm 5.43 \mathrm{~kg}$; height 174.0 $\pm 4.00 \mathrm{~cm}$; BMI; $20.16 \pm 1.43 \mathrm{~kg} / \mathrm{m} 2 ;$ PBF; $12.20 \pm$ $3.96 \%)$ participated in this study. The volunteers were randomly divided into aerobic (4 female, 4 male) and anaerobic (4 female, 4 male) groups. Volunteers participated in a total of 24 training seasons, 3 days per week over 8 weeks. The training programs Involved running on a treadmill in the range of $60-70 \%$ maxHR for 1 hour on each training day for the aerobic group. The anaerobic training program included running in the range of maxHR $80-90 \%$ on the treadmill $(2 * 100$, $2 * 200,2 * 300,1 * 400,2 * 300,2 * 200,2 * 100$ sprints) for 1 hour per season. In order to determine the aerobic performance of the volunteers, a bicycle ergometer (Monark LC6 novo, Varberg, Sweden) was used with a portable gas analyzer (Cosmed K5, Italy).
\end{abstract}

In order to determine the anaerobic performance, a bicycle ergometer (Monark 874 E, Varberg, Sweden), which was connected to a computer modified for the Wingate Anerobic Power Test (WAnT) and compatible with an appropriate piece of software, was used. The study was planned in accordance with a pre-test and post-test model. For statistical evaluation of the data obtained, descriptive statistical methods such as frequency (f), arithmetic mean (X), and standard deviation (SD) were used. A paired-samples t-test was used for the evaluation of the data obtained from pretest and post-test measurements. Independent samples t-test was used for the determination of differences between the sexes. The results were evaluated at the 0.05 significance level. Based on the findings, anaerobic training was observed to cause an increase in all components of anaerobic capacity. Significant differences were found in the anaerobic capacity components. It was found that anaerobic training caused a high level of difference in terms of aerobic capacity values, and thus increased aerobic capacity. It was observed that aerobic training had a positive effect on anaerobic capacity, anaerobic power and the fatigue index. Although aerobic training results in an increase in aerobic capacity of approximately $4 \%$, this increase was not significant.

Key Words: Aerobic Capacity, Anaerobic Capacity, Energy Systems, Physical Fitness

\section{INTRODUCTION}

Activity degree of the practices of various physical exercises as well as the capacity 
of efficiency for an individual or an athletes as they are undertaking a physical activity such as exercise, is to be evaluated as the maximum performance of that individual (Joyner and Coyle, 2008). The main goal of the evaluation of maximum performance is to evaluate the energy amount generated though aerobic and anaerobic metabolism in the skeletal muscle during physical activity. Aerobic capacity is the capacity of large skeletal muscle groups to adapt to work by using energy obtained as a result of aerobic metabolism. Aerobic capacity is used as a physiological criterion to determine the exercise capacity of the athletes. Physiologically, maximum endurance is articulated as the maximum aerobic capacity of the individual. In other words, it is the total oxygen amount used by an individual during an exercise of maximal stress (Tamer, 1996). The peak oxygen volume level used by the skeletal muscles during a gradually increased exercise test is defined as maximum oxygen volume (VO2max). VO2max is a good indicator of aerobic capacity and is considered to be an indicator of the physiological integration of pulmonary, cardiovascular and neuromuscular functions. Anaerobic capacity is the ability of the muscles to adapt to workouts in the form of very short duration, maximal and supramaximal physical activities (Y1ldiz, 2012). The contribution towards technique and tactics by the optimal levels of athletic performance components is indispensable but one should not overlook that technical and tactical mentality and conditional components are complementing factors (Şahin et al., 2017).

Aerobic exercise is a highly crucial conditional component in a variety of branches of sports and the physical fitness of the individuals. In elite athletes, high aerobic power is found to be related to loading during a competition and is reported to help recovering during high-intensity intermittent exercises (Reilly, 1997). Furthermore, the increase in aerobic capacity also increases the capacity of oxygen carrying which then helps recovery of muscle $\mathrm{pH}$ and glycogen consumption during overloads through anaerobic energy (Balsom et al., 1994; Bangsbo, 1994; Tomlin and Wenger, 2001; Impellizzeri et al., 2006). Due to these qualities of aerobic exercise, it is used as one of the primary methods of exercise in many team sports.

Anaerobic workout indicates the use of an explosive power and a load that exceeds anaerobic threshold, and is a physical activity type that presents itself with fatigue. Anaerobic activity cannot be sustained for long periods of time. Because, skeletal muscles are operating way above the steady-rate oxygen metabolism and through anaerobic metabolism. This circumstance increases lactate levels in muscle and blood. The buffering of accumulated lactate increases the $\mathrm{CO} 2$ release from the lungs. Fatigue presents itself in muscles due to decrease of $\mathrm{pH}(\mathrm{pH}=6.4)$ (Jonathan and Euan, 1997). In muscular activities that require maximal generation of energy (about 90 seconds), most of the energy is supplied by ATCP-CP system and anaerobic breakdown of the muscle glycogen (Weltmann, 1995). To increase the energy transfer capacity of ATP-CP, repeated, powerful and short term efforts are needed. These efforts must focus on training of the muscles working during these movements. Metabolic capacity of the muscle fibrils, worked with these types of exercises, increase and the development of the nerve muscle adaptation specific to the sport exercised is increased (McArdle et al., 1996) . Anaerobic high-intensity interval training (HIIT) defines a short period of high intensity (sub-to near maximal) exercise (Hakansson et al., 2018). This exercise model can also be utilized to increase aerobic capacity. The reason for the utilization of this training method to increase aerobic capacity is due the fact that it saves time through short period of efforts (Li et al., 2018; Jakovljevic et al., 2018).

The aim of this study within this context is to research the impacts of aerobic and anaerobic exercises on these energy systems.

\section{METHODS}

\section{Participants}

8 female (age; $18.12 \pm 0.35$ years, weight $46.6 \pm 7.39 \mathrm{~kg}$; height $162.7 \pm 6.75 \mathrm{~cm}$; BMI; $17.72 \pm 2.60 \mathrm{~kg} / \mathrm{m} 2$, PBF; $16.01 \pm 6.15 \%)$ and 8 male (age; $18.50 \pm 1.19$ years, weight $61.18 \pm 5.43$ $\mathrm{kg}$; height $174.0 \pm 4.00 \mathrm{~cm}$; BMI; $20.16 \pm 1.43$ $\mathrm{kg} / \mathrm{m} 2$; PBF; $12.20 \pm 3.96 \%$ ) participated in this study. The study was conducted in line with the principles of Helsinki Declaration of 1975 upon receiving necessary approval.

\section{Training season}

The volunteers were randomly divided into aerobic (4 female, 4 male) and anaerobic (4 female, 4 male) groups. Volunteers participated in a total of 24 training seasons, 3 days per week over 8 weeks. The training programs Involved running on a treadmill in the range of $60-70 \%$ maxHR for 
1 hour on each training day for the aerobic group. $1 \times 400,2 \times 300,2 \times 200,2 \times 100$ sprints) for 1 hour The anaerobic training program included maxHR per season.

$80-90 \%$ on the treadmill $(2 \times 100,2 \times 200,2 \times 300$,

Graphic 1. Eight weeks training period

\section{Training Period}

\section{| || || || || || || || || || || || | | \\ Pre-test 1st 2nd 3rd 4th 5th 6th 7th 8th Post-test}

Monday Wednesday Friday

\section{Measurements and data collection}

Body composition analyzes of the participants were measurement with X-SCAN PLUS II (Jawon Medical, Co, KyungsanCity, Korea). In order to determine the aerobic performance of the volunteers, a bicycle ergometer (Monark LC6 novo, Varberg, Sweden) was used with a portable gas analyzer (Cosmed K5, Italy). In order to determine the anaerobic performance, a bicycle ergometer (Monark 874 E, Varberg, Sweden), which was connected to a computer modified for the Wingate Anaerobic Power Test (WAnT) and compatible with an appropriate piece of software, was used.

\section{Data analysis}

The study was planned in accordance with a pre-test and post-test model. For statistical evaluation of the data obtained, descriptive statistical methods such as frequency (f), arithmetic mean (X), and standard deviation (SD) were used. A paired-samples t-test was used for the evaluation of the data obtained from pre-test and post-test measurements. The data showed normal distribution, so independent samples t-test was used for the determination of differences according to the sexes and post-pretest differences between the groups. The results were evaluated at the 0.05 significance level.

\section{RESULTS}

Table 1. T-test result of pre-test-post-test anaerobic values of anaerobic group

\begin{tabular}{|c|c|c|c|c|c|c|c|}
\hline Variable & Test & $\mathbf{n}$ & $\mathbf{X}$ & SS & $\mathbf{t}$ & $\mathbf{p}$ & $\%$ change \\
\hline \multirow{2}{*}{$\begin{array}{c}\text { Anaerobic Capacity } \\
\text { (Absolute) }\end{array}$} & Pre & \multirow{2}{*}{8} & 407.19 & 105.85 & \multirow{2}{*}{-3.035} & \multirow{2}{*}{$.013 *$} & \multirow{2}{*}{$+\% 5.01$} \\
\hline & Post & & 427.62 & 113.54 & & & \\
\hline \multirow{2}{*}{$\begin{array}{c}\text { Anaerobic Capacity } \\
\text { (Relative) }\end{array}$} & Pre & \multirow{2}{*}{8} & 6.83 & 1.05 & \multirow{2}{*}{-2.333} & \multirow{2}{*}{$.042 \%$} & \multirow{2}{*}{$+\% 3.60$} \\
\hline & Post & & 7.08 & 0.91 & & & \\
\hline \multirow{2}{*}{$\begin{array}{l}\text { Anaerobic Power } \\
\text { (Absolute) }\end{array}$} & Pre & \multirow{2}{*}{8} & 511.40 & 168.96 & \multirow{2}{*}{-2.051} & \multirow{2}{*}{.067} & \multirow{2}{*}{$+\% 5.63$} \\
\hline & Post & & 540.24 & 168.18 & & & \\
\hline \multirow{2}{*}{$\begin{array}{c}\text { Anaerobic Power } \\
\text { (Relative) }\end{array}$} & Pre & \multirow{2}{*}{8} & 8.55 & 2.04 & \multirow{2}{*}{-1.162} & \multirow{2}{*}{.272} & \multirow{2}{*}{$+\% 2.69$} \\
\hline & Post & & 8.78 & 1.60 & & & \\
\hline \multirow{2}{*}{ Fatigue Index } & Pre & \multirow{2}{*}{8} & 39.35 & 15.89 & \multirow{2}{*}{-1.46} & \multirow{2}{*}{.174} & \multirow{2}{*}{$+\% 17.64$} \\
\hline & Post & & 46.67 & 9.71 & & & \\
\hline
\end{tabular}


Statistical analysis of pre and post test results indicate a meaningful increase of anaerobic values as well as the absolute and relative values of anaerobic capacity of the anaerobic group $(\mathrm{p}<0.05)$ (Table $1)$.

Table 2. T-test result of pre-test-post-test aerobic values of anaerobic group

\begin{tabular}{|c|c|c|c|c|c|c|c|}
\hline Variable & Test & $\mathbf{n}$ & $\mathbf{X}$ & SS & $\mathbf{t}$ & p & $\%$ change \\
\hline \multirow{2}{*}{$\begin{array}{l}\text { Aerobic Capacity } \\
\text { (Absolute) }\end{array}$} & Pre & \multirow{2}{*}{8} & 3382.45 & 917.87 & \multirow{2}{*}{-8.783} & \multirow{2}{*}{$.000^{*}$} & \multirow{2}{*}{$+\% 22.18$} \\
\hline & Post & & 4132.77 & 1106.78 & & & \\
\hline \multirow{2}{*}{$\begin{array}{l}\text { Aerobic Capacity } \\
\text { (Relative) }\end{array}$} & Pre & \multirow{2}{*}{8} & 57.88 & 9.45 & \multirow{2}{*}{-8.835} & \multirow{2}{*}{$.000 *$} & \multirow{2}{*}{$+\% 17.91$} \\
\hline & Post & & 68.25 & 9.56 & & & \\
\hline
\end{tabular}

It was identified that anaerobic group displayed a meaningful increase in absolute and relative aerobic values $(\mathrm{p}<0.05)$ (Table 2$)$.

Table 3. T-test result of pre-test-post-test anaerobic values of aerobic group

\begin{tabular}{|c|c|c|c|c|c|c|c|}
\hline Variable & Test & $\mathbf{n}$ & $\mathbf{x}$ & SS & $\mathbf{t}$ & p & $\%$ change \\
\hline \multirow{2}{*}{$\begin{array}{c}\text { Anaerobic Capacity } \\
\text { (Absolute) }\end{array}$} & Pre & \multirow{2}{*}{8} & 398.05 & 105.33 & \multirow{2}{*}{-0.263} & \multirow{2}{*}{.798} & \multirow{2}{*}{$+\% 0.4$} \\
\hline & Post & & 399.70 & 108.58 & & & \\
\hline \multirow{2}{*}{$\begin{array}{l}\text { Anaerobic Capacity } \\
\text { (Relative) }\end{array}$} & Pre & \multirow{2}{*}{8} & 7.59 & 0.65 & \multirow{2}{*}{-0.375} & \multirow{2}{*}{.716} & \multirow{2}{*}{$+\% 0.6$} \\
\hline & Post & & 7.64 & 0.83 & & & \\
\hline \multirow{2}{*}{$\begin{array}{l}\text { Anaerobic Power } \\
\text { (Absolute) }\end{array}$} & Pre & \multirow{2}{*}{8} & 471.96 & 121.42 & \multirow{2}{*}{-4.585} & \multirow{2}{*}{$.001 *$} & \multirow{2}{*}{$+\% 6.5$} \\
\hline & Post & & 502.67 & 110.47 & & & \\
\hline \multirow{2}{*}{$\begin{array}{l}\text { Anaerobic Power } \\
\text { (Relative) }\end{array}$} & Pre & \multirow{2}{*}{8} & 9.11 & 0.96 & \multirow{2}{*}{-2.834} & \multirow{2}{*}{$.018^{*}$} & \multirow{2}{*}{$+\% 6.3$} \\
\hline & Post & & 9.69 & 0.68 & & & \\
\hline \multirow{2}{*}{ Fatigue Index } & Pre & \multirow{2}{*}{8} & 38.73 & 3.62 & \multirow{2}{*}{-4.849} & \multirow{2}{*}{$.001 *$} & \multirow{2}{*}{$+\% 15.28$} \\
\hline & Post & & 44.65 & 4.23 & & & \\
\hline
\end{tabular}

It was seen a meaningful amount of difference is present in the anaerobic values of the aerobic group in terms of absolute and relative values of anaerobic power and fatigue index $(p<0.05)$ (Table 3$)$.

Table 4. T-test result of pre-test-post-test aerobic values of aerobic group

\begin{tabular}{|c|c|c|c|c|c|c|c|}
\hline Variable & Test & $\mathbf{n}$ & $\mathbf{X}$ & SS & $\mathbf{t}$ & p & $\%$ change \\
\hline \multirow{2}{*}{$\begin{array}{l}\text { Aerobic Capacity } \\
\text { (Absolute) }\end{array}$} & Pre & \multirow{2}{*}{8} & 3473.76 & 951.26 & \multirow{2}{*}{-1.488} & \multirow{2}{*}{.168} & \multirow{2}{*}{$+\% 4.61$} \\
\hline & Post & & 3634.23 & 1026.27 & & & \\
\hline \multirow{2}{*}{$\begin{array}{l}\text { Aerobic Capacity } \\
\text { (Relative) }\end{array}$} & Pre & \multirow{2}{*}{8} & 64.91 & 8.07 & \multirow{2}{*}{-0.967} & \multirow{2}{*}{.356} & \multirow{2}{*}{$+\% 3.07$} \\
\hline & Post & & 66.94 & 8.51 & & & \\
\hline
\end{tabular}

Even though an increase can be observed in the aerobic values of the aerobic group, it is not statistically meaningful ( $>00.05)$ (Table 4). 
Table 5. T-test results of the difference between post-test and pre-test parameters of aerobic and anaerobic training groups

\begin{tabular}{|c|c|c|c|c|c|c|}
\hline Variable & Group & $\mathbf{n}$ & $\mathbf{X}$ & SS & $\mathbf{t}$ & p \\
\hline \multirow{2}{*}{$\begin{array}{c}\text { Anaerobic Capacity } \\
\text { (Absolute) }\end{array}$} & Anaerobic & & 19.42 & 23.16 & \multirow{2}{*}{1.790} & \multirow{2}{*}{.095} \\
\hline & Aerobic & & -1.12 & 22.73 & & \\
\hline \multirow{2}{*}{$\begin{array}{c}\text { Anaerobic Capacity } \\
\text { (Relative) }\end{array}$} & Anaerobic & & 9.42 & 4.18 & \multirow{2}{*}{3.084} & \multirow{2}{*}{$.008 *$} \\
\hline & Aerobic & & 0.35 & 7.18 & & \\
\hline \multirow{2}{*}{$\begin{array}{l}\text { Anaerobic Power } \\
\text { (Absolute) }\end{array}$} & Anaerobic & & 31.69 & 51.64 & \multirow{2}{*}{0.195} & \multirow{2}{*}{.849} \\
\hline & Aerobic & & 27.81 & 22.48 & & \\
\hline \multirow{2}{*}{$\begin{array}{l}\text { Anaerobic Power } \\
\text { (Relative) }\end{array}$} & Anaerobic & \multirow{2}{*}{8} & 0.13 & 0.63 & \multirow{2}{*}{-1.101} & \multirow{2}{*}{.290} \\
\hline & Aerobic & & 0.52 & 0.77 & & \\
\hline \multirow{2}{*}{ Fatigue Index } & Anaerobic & & 8.34 & 18.85 & \multirow{2}{*}{0.243} & \multirow{2}{*}{.812} \\
\hline & Aerobic & & 6.69 & 4.05 & & \\
\hline \multirow{2}{*}{$\begin{array}{l}\text { Aerobic Capacity } \\
\text { (Absolute) }\end{array}$} & Anaerobic & & 693.33 & 295.96 & \multirow{2}{*}{3.823} & \multirow{2}{*}{$.002 *$} \\
\hline & Aerobic & & 56.74 & 366.41 & & \\
\hline \multirow{2}{*}{$\begin{array}{l}\text { Aerobic Capacity } \\
\text { (Relative) }\end{array}$} & Anaerobic & & 9.42 & 4.18 & \multirow{2}{*}{3.084} & \multirow{2}{*}{$.008 *$} \\
\hline & Aerobic & & 0.35 & 7.18 & & \\
\hline
\end{tabular}

According to the difference between the post-test pre-test parameters of the difference between aerobic and anaerobic training groups; There was a statistically significant difference in Anaerobic Capacity (Relative), Aerobic Capacity (Absolute) and Aerobic Capacity (Relative) values in favor of anaerobic training group.

\section{DISCUSSION AND CONCLUSION}

Based on the findings, anaerobic training was observed to cause an increase in all components of anaerobic capacity. Significant differences were found in the anaerobic capacity components. It was found that anaerobic training caused a high level of difference in terms of aerobic capacity values, and thus increased aerobic capacity. Another result from the anaerobic exercise group is that, following the exercise period there exists no change in fat-free mass. Yüksel et al., (2007) displayed that continuous and interval exercises conducted for three days a week for eight weeks; interval exercises had no impact on body mass, body fat ratio and anaerobic power levels. In our study as well, even though positive impacts of anaerobic exercises on anaerobic capacity are seen, it holds no influence on body fat ratio, fat free body mass and anaerobic power. Another study of similar nature, found an increase of $15.4 \%$ statistically relevant/meaningful, VO2max levels of $42.33 \mathrm{~mL} / \mathrm{kg} / \mathrm{min}$ before the exercise and $48.85 \mathrm{~mL} / \mathrm{kg} / \mathrm{min}$ after, following a ten-week exercise with extensive interval method conducted in male basketball players aging 13-14 years (Erol et al., 1997). Our study points towards similar results with an increase of $\% 17.91$ in relative VO2max levels.

According to another result obtained from our study; it was observed that aerobic training had a positive effect on anaerobic capacity, anaerobic power and the fatigue index. Although aerobic training results in an increase in aerobic capacity of approximately $4 \%$, this increase was not significant statistically. Short et al, (2004) found a $9 \%$ increase in the aerobic capacities of the participants following an aerobic exercise program of for months in a study. The same study displayed no difference in fat free body mass. In our study, since the study period was limited to two months, we observed a $\% 4$ increase in aerobic capacity. In line with these results, it is conceivable that aerobic capacity can be increased with aerobic exercise method through an extended/long exercise program. However, our study displayed a decrease in fat free body mass in contrast of the other study. This discrepancy could have been caused by the utilization of the treadmill exercise, which uses more muscle groups, in contrast to bicycle exercise 
(Sözen, 2010). This result is supported by another study too (Short et al., 2003). There are also studies that indicate aerobic exercise has no meaningful impact on aerobic capacity, and the exercise period of these studies are reported to be between six and eight weeks (Helgerud et al., 2001; Impellizzeri et al., 2006). Another study of similar nature by Overend et al., (1992) reports the benefits of high and low intensity interval exercises carried on for ten weeks on VO2max levels through continuous exercise.

When the difference between the posttest pre-test parameters are examined according to the differences between the aerobic and anaerobic training groups; Anaerobic Capacity (Relative), Aerobic Capacity (Absolute) and Aerobic Capacity (Relative) values in favor of the anaerobic training group compared to the aerobic training group. According to this result, it can be said that anaerobic training has more effect on both anaerobic and aerobic capacity according to aerobic training.

The inclusion of anaerobic exercise methods in exercise types that aim to increase aerobic capacity could prove beneficial in the enhancement of aerobic capacity. Furthermore however regarding the fatigue index, to which the decrease in power during the anaerobic test is mapped as a percentage, it can be argued that aerobic exercise has a negative impact on it and hence a decrease in anaerobic continuity. The availability of anaerobic training methods in the types of training that aim to improve aerobic capacity can help to increase aerobic capacity and also it is recommended to take part in aerobic training because of the positive effects on anaerobic power, which is thought to be based on alactic anaerobic processes.

Acknowledgements: We would like to thank all the subjects who volunteered their time to participate in this study. The study was presented as poster presentation at The International Balkan Conference in Sport Sciences (21-23 May 2017, Bursa/Turkey).

Conflict of interest: The authors declare that they have no conflict of interest.

\section{REFERENCES}

Balsom PD., Ekblom B., Sjodin B. (1994) Enhanced oxygen availability during high intensity intermittent exercise decreases anaerobic metabolite concentrations in blood. Acta Physiol Scand 150:455-456.
Bangsbo J. (1994) The physiology of soccer - with special reference to intense intermittent exercise. Acta Physiol Scand 619(Suppl):1-155.

Erol E, Tamer K, Sevim Y, Cicioğlu İ, Çimen O. (1997) Yaygın interval metot ile uygulanan dayanıklılık çalışmalarının 13-14 yaş grubu basketbolcuların aerobic-anaerobik güç ve bazı fiziksel parametreler üzerine etkilerinin incelenmesi. Performans Dergisi 3(1):7-15.

Hakansson S, Jones MD, Ristov M, Marcos L, Clark T, Ram A, Morey R, Franklin A, McCarthy C, Carli L, Ward R, Keech A. (2018) Intensity-dependent effects of aerobic training on pressure pain threshold in overweight males: a randomized trial. Eur J Pain 22:1813-1823.

Helgerud J, Engen LC, Wisloff U, Hoff J. (2001) Aerobic endurance training improves soccer performance. Med sci Sports Exerc 33:1925-1931.

Impellizzeri FM, Marcora SM, Castagna C, Reilly T, Sassi A, Iaia FM, Rampinini E. (2006) Physiological and performance effects of generic versus specific aerobic training in soccer players. Int J Sports Med 27(6):483-492.

Jakovljevic B, Turnic TN, Jeremic N, Jeremic J, Bradic J, Ravic M, Jakovljevic VL, Jelic D, Radovanovic D, Pechanova O, Zivkovic V. (2018) The impact of aerobic and anaerobic training regimes on blood pressure in normotensive and hypertensive rats: focus on redox changes. Molecular and Cellular Biochemistry https:// doi.org/10.1007/s11010-018-3457-y

Jonathan M, Euan A. (1997) A perspective on exercise, lactate, and the anaerobic threshold. Chest 111:787795.

Joyner MJ, Coyle EF. (2008) Endurance exercise performance: The physiology of champions. J Physiol 586(1):35-44.

Li FH, Li T, Ai JY, Sun L, Min Z, Duan R, Zhu L, Liu YY, Liu TC. (2018) Beneficial autophagic activities, mitochondrial function, intensity interval training in a rat model, Front Physiol 9:571.

McArdle WD, Katch FI, Katch VL. (1996) Exercise Physiology: Energy, Nutrition, and Human Performance. Baltimore, MD: Williams \& Wilkins 316.

Overend TJ, Paterson DH, Cunningham DA. (1992) The effects of interval and continuous training on the aerobic parameters. Can J Sport Sci 17(2):129-34.

Reilly T. (1997) Energetics of high-intensity exercise (soccer) with particular reference to fatigue. J Sports Sci 15:257-263.

Short KR, Vittone JL, Bigelow ML, Proctor DN, Rizza 
RR, Coenen-Schimke Jm, Nair KS. (2003) Impact of aerobic training on age-related changes in insulin action and muscle oxidative capacity. Diabetes 52:1888-1896.

Short KR, Vittone JL, Bigelow ML, Proctor DN, Nair KS. (2004) Age and aerobic exercise training effects on whole body and mucle protein metabolism. Am J Physiol Endocrinol Metab 286:E92-E101.

Sözen H. (2010) Comparison of muscle activation during elliptical trainer, treadmill and bike exercise. Biol. Sport 27:203-206.

Şahin M., Kırandı Ö., Uysal M. (2017) Gelişim ligi futbolcularında aerobik dayanıklılık özelliğinin müsabaka performansıyla ilişskisi. Spor Eğitim Dergisi 1(1):34-41.

Tamer K. (1996) Farklı aerobik antrenman programlarının serum hormonları, kan lipidleri ve vücut yağ yüzdeleri üzerine etkileri. Bed. Eğt. Spor Bil. Der 1(1):1-11.

Tomlin DL, Wenger HA. (2001) The relationship between aerobic fitness and recovery from high intensity intermittent exercise. Sport Med 31:1-11.

Weltmann A. (1995) The Blood Lactate Response to Exercise, Champaign, IL: Human Kinetics 117p.

Y1ldız SA. (2012) Aerobik ve anaerobik kapasitenin anlamı nedir? Solunum 14(Ek):1-8.

Yüksel O, Koç O, Özdilek Ç, Gökdemir K. (2007) Sürekli ve interval antrenman programlarının üniversite öğrencilerinin aerobic ve anaerobic gücüne etkisi. Sağlık Bilimleri Dergisi 16(3):133-139. 